\section{Genetic Characterization of an Unknown Chinese Bulbous Leek-like Accession and its Relationship to Similar Allium Species}

Borut Bohanec, ${ }^{1}$ Marijana Jakše, and Predrag Šesek University of Ljubljana, Biotechnical Faculty, Centre for Plant Biotechnology and Breeding, Jamnikarjeva 101, 1111 Ljubljana, Slovenia

Michael J. Havey

Agricultural Research, U.S. Department of Argiculture, Department of Horticulture, 1575 Linden Drive, University of Wisconsin, Madison, WI 53706

Additional index words. Allium ampeloprasum, bulbous leek, great-headed garlic, karyotype, flow cytometry, GISH, DNA polymorphism

\begin{abstract}
Bulbous leek-like plants are a poorly defined group usually assigned to the Allium ampeloprasum complex. Studies were initiated to determine the origin of an unusual bulbous accession received in Shanxi province in China, where it was used in diet as garlic but propagated by seeds, and to genetically compare this accession with morphologically similar plants from Europe. Genetic analyses included karyotypes and genomic in situ hybridization, pollination to leek, genome size determination and nuclear rDNA and plastid DNA polymorphisms. Results revealed that this agriculturally interesting accession from China is a so far unknown variant within tetraploid $A$. ampeloprasum cultivated taxa. We also observed that great-headed garlic did not share derived states in the chloroplast with leek, revealing that this cultivated plant does not possess the cytoplasm of leek or garlic, while its $1 \mathrm{C}$ genome size was $17 \%$ bigger than those of studied leek and bulbous-leek accessions.
\end{abstract}

The genus Allium L. contains about 700 species, several of which are edible and are among man's most ancient cultivated crops. The edible alliums and their areas of cultivation have been recently reviewed by Fritsch and Friesen (2002). The large number of Allium species and the diversity among the cultivated forms, which are spread across diverse climates throughout the Northern hemisphere, permits for the occasional discovery of new cultivated forms, not yet well described. Most botanical classifications of species were based on morphological characterizations, however modern genetic techniques can provide new insights regarding phylogenetic relationships.

Major crops within subgenus Allium section Allium are A. sativum L. (garlic) and the various cultivated forms of $A$. ampeloprasum L. According to Mathew (1996), A. ampeloprasum is widespread through out the Mediterranean region and Middle Eastern countries; however, populations have been recorded in other areas possibly due to ancient introductions. Using the botanical terminology of Matthew (1996), wild $A$. ampeloprasum is thought to be the progenitor form of crop plants $A$. porrum $\mathrm{L}$. (leek) and A. kurrat Schweinf., both cultivated for their leaves. A third variant, termed great-

Received for publication 7 Apr. 2005. Accepted for publication 21 June 2005. We are grateful to Lin Rufa, Shanxi Academy of Agricultural Sciences and Charles-Marie Messiaen (Le Teil, France) for providing accessions used in this study. This research was supported in part by project P4-0077.

${ }^{1}$ Corresponding author; e-mail borut.bohanec@bf. uni-lj.si. headed garlic, is cultivated for its bulbs and asexually propagated. Mathew (1996) states that great-headed garlic closely resembles $A$. ampeloprasum and does not warrant classification as a separate species. Mathew (1996) also described $A$. commutatum Guss. and A. bourgeaui Rech. as closely related to $A$. ampeloprasum. Similarly Brewster (1994), following the classification proposed by Hanelt (1990), cites two major crop species within subgenus Allium section Allium: A. sativum (garlic) and A. ampeloprasum classified into the four horticultural groups of leek, kurrat, great-headed garlic and pearl onion. Based on their use, Messiaen et al. (1993) classified leek-like plants as A. polyanthum Schultes, A. ampeloprasum (sensu stricto), A. commutatum and $A$. scorodoprasum L.. These authors mention that wild $A$. ampeloprasum var. bulbiferum (from Yeu Island, off Western France) and Great Headed Garlic are chemically closer to garlic.

The ploidy levels of bulbous leek-like plants are highly variable. As recently reviewed by Mathew (1996), the chromosome numbers of A. ampeloprasum ranged from 16 to $56, A$. porrum from 32 to $48, A$. kurrat at $32, A$. commutatum from 16 to 48 , and $A$. polyanthum at 32. The predominant ploidy level among these species is tetraploid (32), while other ploidies are less frequent and may be associated with vegetative propagation. Allium ampeloprasum, A. porrum and A. commutatum may possess variable numbers of B chromosomes.

Our studies focused on the genetic characterization of economically useful forms of bulbous alliums with leaf morphologies similar to leek. We concentrated on an unusual accession received in Shanxi province, China, where it is seed propagated but used in diets as garlic. Studies included the majority of morphologically similar alliums, using karyotype analysis, genomic in situ hybridization(GISH), pollination, genome size determination and molecular markers using nuclear rDNA and plastid cpDNA probes.

\section{Material and Methods}

Plant material. In Shanxi province, China, in 1996, local agronomists gave B. Bohanec and M. Jakše two accessions of an Allium described as seed-forming garlic. No further information on the origin of these accessions could be obtained. These accessions obtained in Shanxi province in China will be referred to as chinese bulbous leek. Plants were raised from seeds and maintained in the experimental field of the Biotechnical Faculty in Ljubljana. Sensory evaluation was done by 10 panelists, each of whom was given bulbs of garlic and chinese bulbous leek. The taste attributes (aroma intensity, crispness, and pungency (scale $1=$ low, 5 = high intensity) were assessed immediately after peeling and cutting samples.

Leaves and bulb tissues were obtained from A. polyanthum - two accessions (the first from St. Mandrier sur Mer, France and the second from Ile d'Yeu, France - for the second, determination of species was noted as not certain), A. commutatum (from Corsica), two accessions of great-headed garlic (from Spain and from India), and three forms of bulbous leeks - one from Ile d'Yeu (France), one from Apt (France) and one from Guadeloupe were kindly provided by C.M. Messiaen (Le Teil, France), from his personal collection. Additional samples that were included in studies were bulb onion, leek, garlic, bunching onion and A. tuberosum Rottl., which were either commercial varieties or accessions used in other genetic studies at the University of Wisconsin.

Chromosome preparations. The root tips were excised from 1- to 2-cm-long roots obtained after germinating on moist filter paper at $25{ }^{\circ} \mathrm{C}$. They were then treated by a $1 \%$ $(\mathrm{v} / \mathrm{v})$ solution of monobromonaphtalene for $24 \mathrm{~h}$ at $4{ }^{\circ} \mathrm{C}$ or by $2 \mathrm{~mm} 8$-hydroxyquinoline for 0.5 to $2 \mathrm{~h}$ at room temperature followed by storing for a further 0.5 to $2 \mathrm{~h}$ at $4{ }^{\circ} \mathrm{C}$. The tissue was fixed in Farmer's fixative at for at least $24 \mathrm{~h}$ at $4{ }^{\circ} \mathrm{C}$. Root tips were digested in $4 \%$ cellulase (Onozuka) and 1\% pectolyase (Y23) for $45 \mathrm{~min}$ before squashing in $45 \%$ acetic acid. Cover slips were removed after freezing at $-80^{\circ} \mathrm{C}$ and the slides were dried. For karyotype analysis chromosomes were stained with $2 \mu \mathrm{g} \cdot \mathrm{mL}^{-1}$ 4'-6-diamidino-2-phenylindole (DAPI). The best quality preparations were used for chromosome counting and arranging into karyograms on the basis of increasing chromosome length. Measurements of chromosome length were performed using the program Image-Pro Express 4.0.

Genomic in situ hybridization. Total genomic DNA was isolated from young leaves using standard cationic detergent cetyl-tri- 
methylammonium bromide (CTAB) method. Total genomic DNA from leek, bulbous leek, garlic and great-headed garlic was labeled with biotin using BioNick labeling kit (Life Technologies) according to the supplier's instructions. Total genomic DNA of garlic, leek and of the undetermined Allium species was fragmented by autoclaving for $6 \mathrm{~min}$ and used as blocking DNA. Following standard RNase and pepsin treatments, in situ hybridization and probe detection were performed according to a procedure modified from Puizina et al. (1999). Briefly, chromosomes were denatured in $70 \%$ formamide in $2 \times \mathrm{SSC}$ for $2 \mathrm{~min}$ at 70

${ }^{\circ} \mathrm{C}$, dehydrated through a cold ethanol series and air dried. The probe mixture, containing 40 to $200 \mathrm{ng}$ of biotinylated genomic DNA, 20 to 60 times that amount of blocking DNA (when used), 50\% deionized formamide, 10\% dextran sulphate, salmon sperm DNA and $2 \times$ SSC, was denatured at $80^{\circ} \mathrm{C}$ for $10 \mathrm{~min}$, and then immediately put on ice for $5 \mathrm{~min}$. The denatured probe mixture was applied on the denatured chromosome preparation. Hybridization was carried out overnight in a humid chamber at $37^{\circ} \mathrm{C}$. After the hybridization step the slides were washed $2 \times$ for $5 \mathrm{~min}$ in $50 \%$ formamide in $2 \times \mathrm{SSC}$ and $1 \times 5 \mathrm{~min}$ in $2 \times \mathrm{SSC}$ at $42{ }^{\circ} \mathrm{C}\left(37\right.$ or $60{ }^{\circ} \mathrm{C}$ were used for different stringency), followed by $10 \mathrm{~min}$ in $2 \times \mathrm{SSC}$ at room temperature. The slides were then washed $5 \mathrm{~min}$ in detection buffer containing $4 \times$ SSC and $0.2 \%$ Tween- 20 and incubated for $30 \mathrm{~min}$ at $37{ }^{\circ} \mathrm{C}$ with detection reagent containing $3 \%$ bovine serum albumin (BSA), $4 \times$ SSC and $0.2 \%$ Tween- 20 . For detection of hybridization sites slides were incubated with streptavidin-conjugated Cy3 $\left(2.5 \mu \mathrm{g} \cdot \mathrm{mL}^{-1}\right)$ in detection reagent for 60 min at $37^{\circ} \mathrm{C}$. After that the slides were subsequently washed in detection buffer $3 \times$ for $5 \mathrm{~min}$ at room temperature. The slides were mounted in antifade solution containing $0.2 \mu \mathrm{g} \cdot \mathrm{mL}^{-1}$ of DAPI. Photographs were taken with a Zeiss MC 80 camera mounted on a Jenalumar 250 (Carl Zeiss) fluorescence microscope with an appropriate filter system using Fuji 1000 color dia film. All in situ hybridizations were repeated, varying proportions of labeled DNA and blocking DNA and using a different temperature of stringency washing, for a more reliable result.

Pollination studies and confirmation of hybrid origin. The fertility of chinese bulbous leek was tested using pollen from 'Elefant' leek. When fertile chinese bulbous leek was used as the female parent, hand emasculation was performed on about 100 flowers followed by a hand pollination with leek pollen. Hybrid origins of progenies were tested by the RAPD method using primers OPA-01, OPA-19, and OPA-20 as previously reported (Campion et al., 1995).

Genome size determination. Genome size was determined using flow cytometry. Nuclei were isolated by chopping young leaf tissue from all studied accessions and standard species (Allium cepa L. or Vicia faba L.) in an ice-cold LB-01 buffer (Dolezel et al., 1989), passed through $30 \mu \mathrm{m}$ nylon filter and stained with $50 \mu \mathrm{g} \cdot \mathrm{mL}^{-1} \mathrm{RNAse}$ and $50 \mu \mathrm{g} \cdot \mathrm{mL}^{-1}$ propidium iodide. A generally accepted (Dolezel et al., 1998) genome size for onion (33.5 pg per nucleus) was used as standard from which others including Vicia faba were calculated. For measurements, samples of the studied accession were mixed with species used as standard, data are based on four repetitions, and analysis was completed within 3 to minimize seasonal variation effect.

Hybridizations using nuclear rDNA and cpDNA probes. Variation was assessed at previously characterized polymorphisms in the chloroplast and nuclear $45 \mathrm{~s}$ ribosomal (r) DNAs, which can distinguish $A$. ampeloprasum and $A$. sativum. The nuclear $45 \mathrm{~s}$ rDNAs were distinguished using polymorphisms at or between DraI, EcoRI, EcoRV, and $X b a \mathrm{I}$ (Havey, 1992). The cytoplasms were differentiated using chloroplast characters 7, 9, and 13 (Havey, 1991). Genomic DNAs were isolated
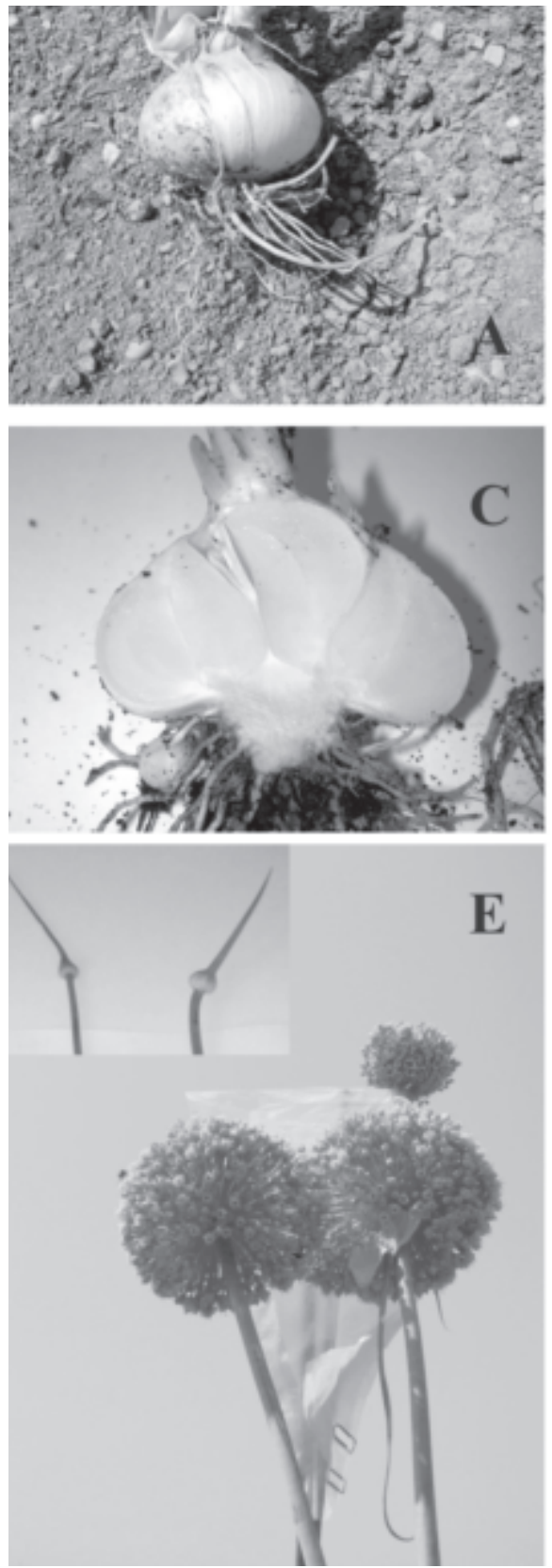

using CTAB procedure as described by SaghaiMaroof et al. (1984). Digestions, transfers to filters, hybridizations, autoradiography, and scoring of polymorphisms were as previously reported (Havey, 1991, 1992).

\section{Results}

Morphological characteristics of an accession of chinese bulbous leek. Chinese bulbous leek formed, partially depending on growth conditions, more or less typical leek-like pseudostems. At the end of the first vegetation year a single bulb (round) was formed (Fig. 1A). At the end of the second year of vegetative growth (Fig. 1B), bulbs were composed of several cloves (Fig. 1C and D). Flower stalks were formed in the second growth year and during later years, forming at first leek-like
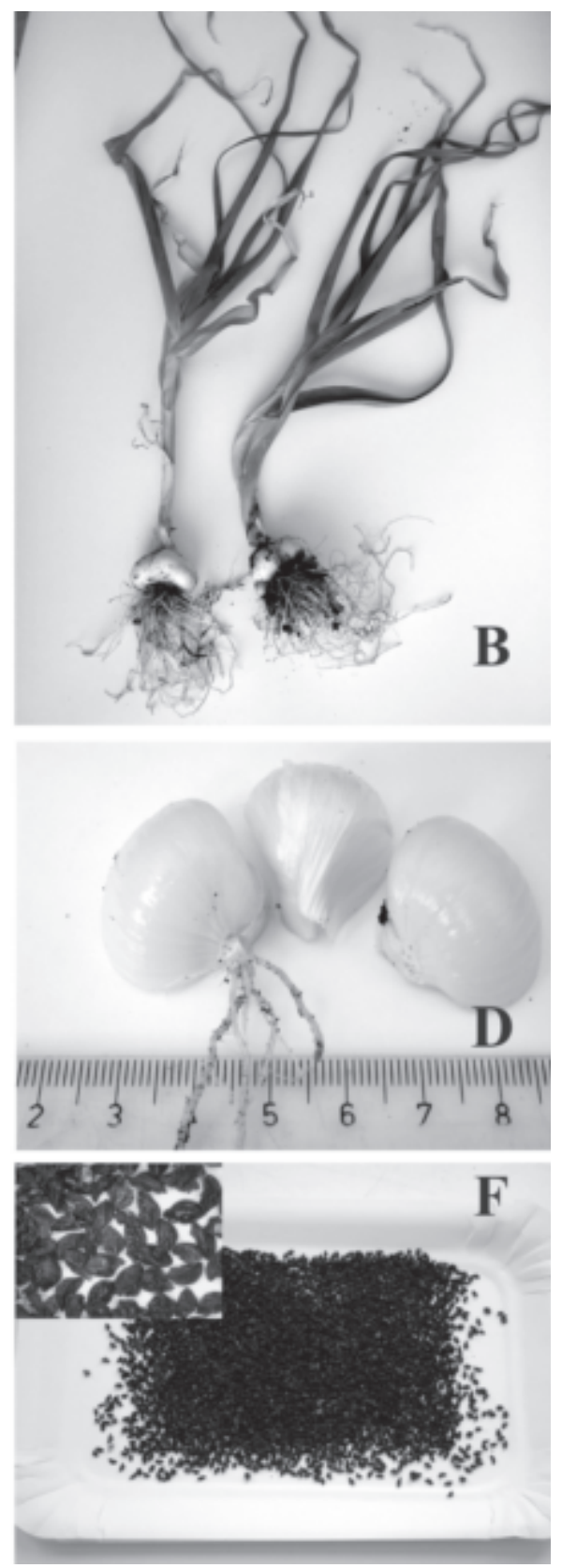

Fig. 1. Morphological characteristics of an accession of chinese bulbous leek: (A) round bulbs formed after first growth year, (B) plants at maturity after second growth year, $(\mathbf{C})$ cross section of bulb, (D) separated individual cloves, $(\mathbf{E})$ immature and mature inflorescences, and $(\mathbf{F})$ seeds from a single plant 
leafy spathes and later large inflorescences (Fig. 1E) which after cross pollination produced large number of fertile seeds (Fig. 1F).

Organoleptic properties of the bulbs were similar to those of garlic but with some distinctive differences. Average scores were 2.94 and 2.33 for aroma, 2.60 and 4.40 for crispness and 4.80 and 1.45 for pungency for garlic and chinese bulbous leek respectively.

Chromosomal studies. Chromosome counting revealed that chinese bulbous leek possessed the tetraploid chromosome number $(2 n=4 x=32)$. In the majority of chromosome spreads, there were 2 to 4 minor (B) chromosomes. Figure 2A and B shows typical karyotype and karyogram of metaphase spreads, including $4 \mathrm{~B}$-chromosomes.

GISH analysis of chinese bulbous leek. GISH was used to assess the degree of cross hybridization among four putative related species-leek, a European accession of bulbous leek, great-headed garlic and garlic. Hybridization to chinese bulbous leek with DNA from leek or the European accession of bulbous leeks produced strong and uniform hybridization signals, while hybridizations with DNA from great-headed garlic and garlic produced only faint and fragmented signals. Examples of strong and faint hybridization signals are shown in Fig. $3 \mathrm{~A}$ and $\mathrm{B}$.

Genome sizes. The genome size of chinese bulbous leek was compared to morphologically similar Allium species (Table 1) and was close to those measured previously for leek, garlic and great-headed garlic (Walters, 1992). The genome sizes for bulbous leeks, A. polyanthum and $A$. commutatum have not been previously reported. Our sample of $A$. commutatum was, according to its genome size, hexaploid, which has not been previously reported for this species. Accessions formed three distinct groups. Chinese bulbous leek, a commercial variety of leek and two European accessions of bulbous leeks formed the first group (average 13.223 pg), great-headed garlic formed the second group (average $15.482 \mathrm{pg}$ ), which was close to $A$. polyanthum and A. commutatum (average $15.626 \mathrm{pg}$ ), and a commercial variety of garlic $(17.118 \mathrm{pg})$ formed the third group. Our results indicate that chinese bulbous leek is more closely related to accessions of bulbous leeks grown in Europe belonging to $A$. ampeloprasum group than to other alliums in this study. This group differed significantly from garlic, great-headed garlic, and the two wild species $A$. polyanthum and $A$. commutatum. On the other hand, greatheaded garlic was very close in genome size to the two wild species $A$. polyanthum and $A$. commutatum, but different from garlic (Table 1). This is a new finding.

Polymorphisms in the nuclear ribosomal and chloroplast DNAs. The accession of chinese bulbous leek was identical to $A$. ampeloprasum for polymorphisms 7, 9, and 13 (Havey, 1991) in the chloroplast DNA (Fig. 4). Maternal phylogenies estimated using polymorphic restriction enzyme sites in the chloroplast genome support a well defined clade for $A$. ampeloprasum and $A$. sativum (Havey, 1991). These three chloroplast characters distinguishing $A$. ampeloprasum and $A$. sativum were unique (autapomorphies) to $A$. ampeloprasum. Because these autapomorphic characters represent the derived, and not the progenitor, states, these chloroplast analyses strongly support the classification of chinese bulbous leek as a cultivated form of $\mathrm{A}$. ampeloprasum, and not of garlic.
Polymorphisms in the nuclear $45 \mathrm{~s}$ rDNA agreed with the chloroplast evaluations. The accessions of chinese bulbous leek possessed the same sized fragments as leek and bulbous leek for all fragments in the nuclear $45 \mathrm{~s} \mathrm{rDNA}$ generated by DraI,EcoRI(Fig. 5), EcoRV, and $X b a$ I digests (Havey, 1992). Highly conserved
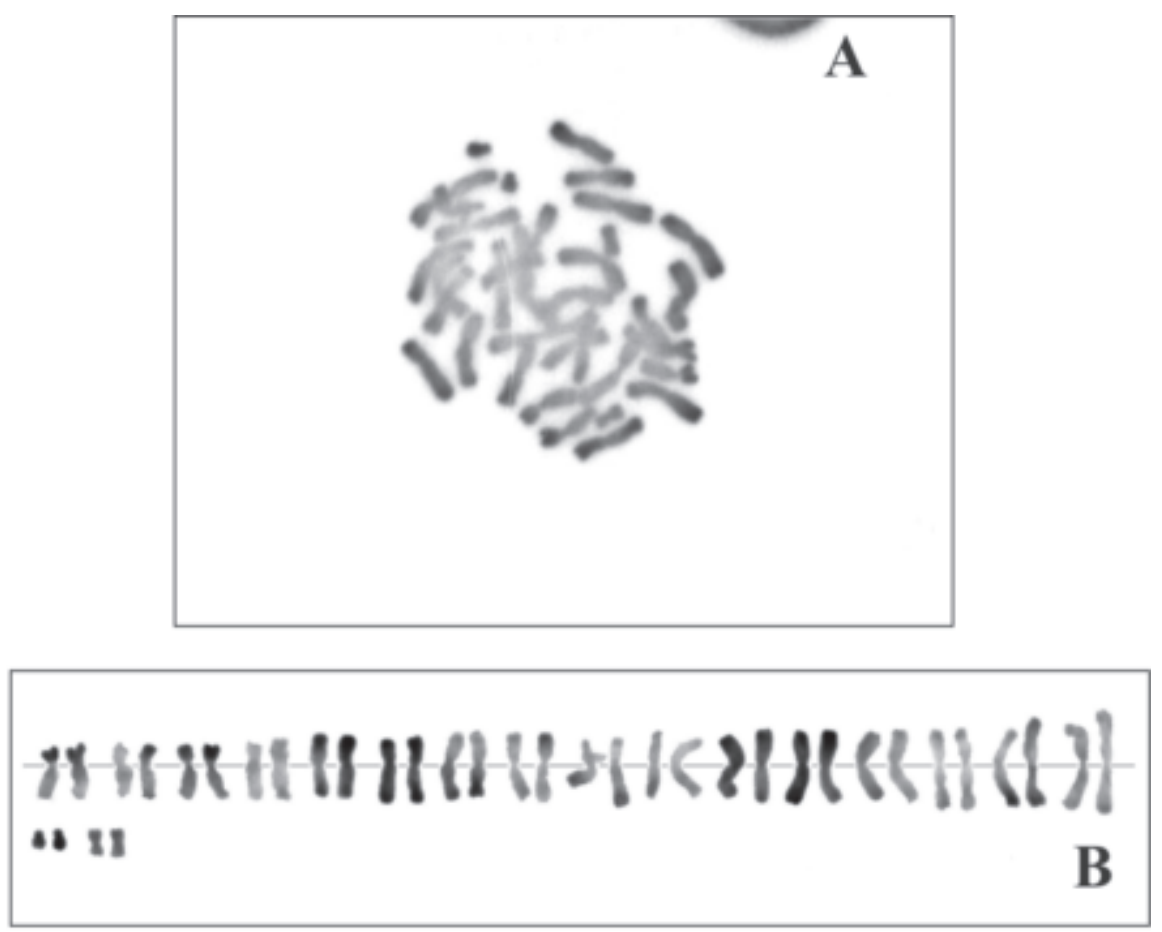

Fig. 2. Root tips metaphase spread of chinese bulbous leek chromosomes: (A) karyotype and (B) karyogram
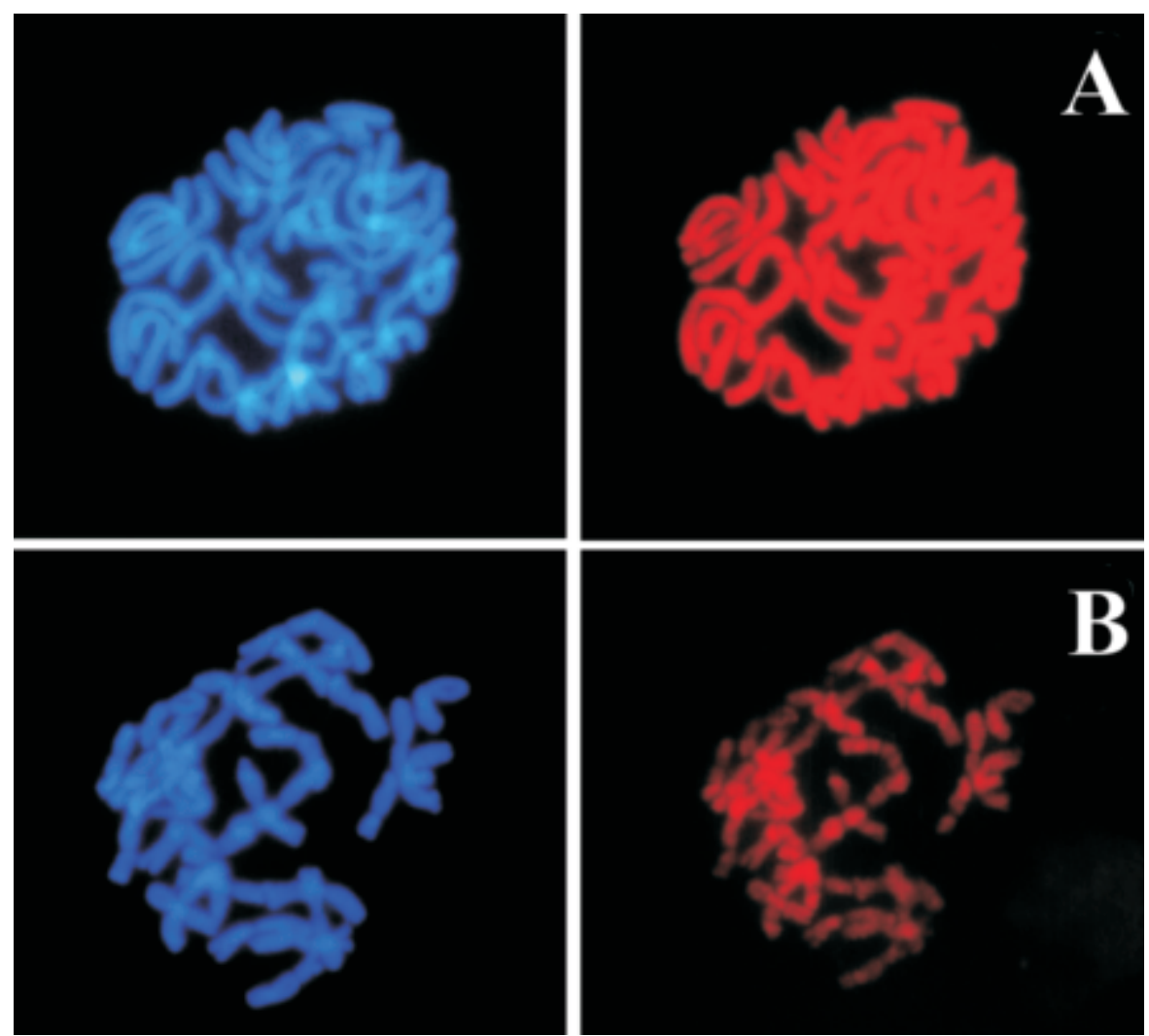

Fig. 3. GISH analysis (left DAPI and right CY3 fluorescence) on chromosomes of chinese bulbous leek hybridized with (A) european bulbous leek accession from Apt and (B) 'Thermidrome' garlic. 
Table 1 . Genome sizes of studied Allium species as revealed by flow cytometry.

\begin{tabular}{lcc}
\hline Species & $\begin{array}{c}\text { Total genome } \\
\text { size (pg) }\end{array}$ & $\begin{array}{c}\text { Estimated ploidy level } \\
\text { and 1C value (pg) }\end{array}$ \\
\hline Chinese bulbous leek* & $52.598 \pm 0.289$ & $4 \mathrm{n}-13.149$ \\
'Ardea' leek* & $52.719 \pm 0.438$ & $4 \mathrm{n}-13.180$ \\
Bulbous leek (Guadeloupe)* & $52.634 \pm 0.976$ & $4 \mathrm{n}-13.158$ \\
Bulbous leek (Apt)* & $53.625 \pm 0.245$ & $4 \mathrm{n}-13.406$ \\
Allium polyanthum (St. Mandrier sur Mer)* & $61.060 \pm 0.706$ & $4 \mathrm{n}-15.265$ \\
Allium commutatum (Corsica) ** & $92.222 \pm 0.889$ & $6 \mathrm{n}-15.370$ \\
Great-headed garlic (Spain)** & $92.774 \pm 0.703$ & $6 \mathrm{n}-15.462$ \\
Great-headed garlic (India)** & $93.021 \pm 0.608$ & $6 \mathrm{n}-15.503$ \\
'Thermidrome' garlic* & $34.236 \pm 0.582$ & $2 \mathrm{n}-17.118$ \\
\hline
\end{tabular}

*Standard Allium cepa (33.5 pg).

**Standard Vicia faba $(25.412 \mathrm{pg})$.

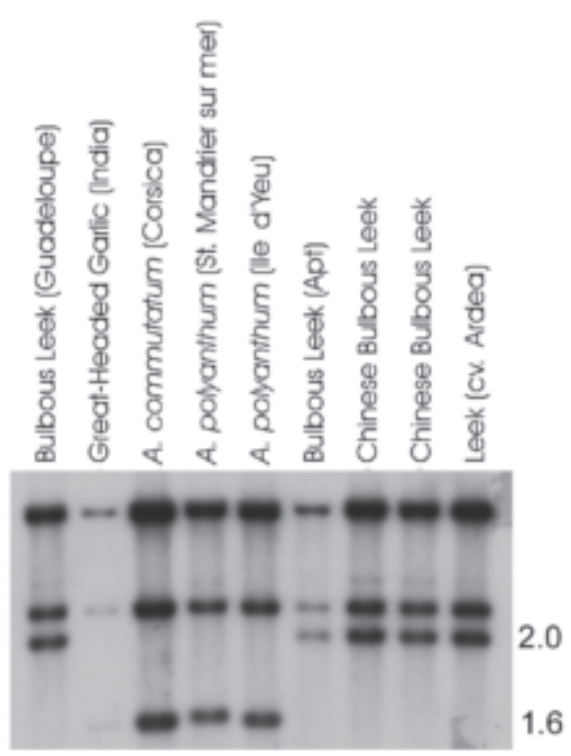

Fig. 4. Autoradiogram showing polymorphism 9 (Havey, 1991) in the chloroplast DNA of the alliums listed across the top. Sizes in kilobases of polymorphic fragments listed on right.

EcoRI sites in the $18 \mathrm{~s}$ and 26 s coding regions produce a 3.6-kb fragment shared among all alliums analyzed to date (Havey, 1992). Variation in the sizes of the intergenic spacer (fragments larger than $3.6 \mathrm{~kb}$ in Fig. 5) or additional EcoRI sites (2.6-kb fragments in Fig. 5) generated RFLPs among the Allium species (Havey, 1992).

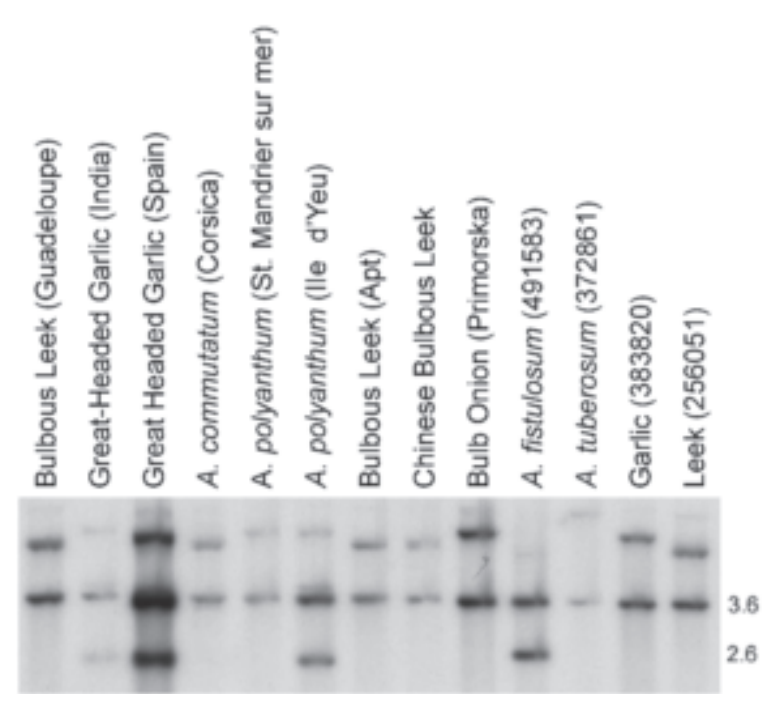

Chromosomal studies of our accession of

\section{Discussion} ated from tetraploid A. ampeloprasum both in the chloroplast genome (Fig. 4), as previously reported by Havey and Leite (1999), and nuclear 45s rDNA (Fig. 5). In the chloroplast genome, great-headed garlic possessed the progenitor states for all three polymorphisms. Spanish great-headed garlic shared a $2.6-\mathrm{kb}$ fragment, produced by an EcoRI site in the rDNA intergenic spacer (Havey, 1992), with bunching onion (A. fistulosum L.) and one accession (from Ile d'Yeu) of $A$. polyanthum (Fig. 5). The largest fragment in great-headed garlic revealed by hybridization of the rDNA probe to EcoRI digests was clearly larger than the largest fragment in leek. Although great-headed garlic has been classified as an A. ampeloprasum (Mathew, 1996), the leeks and great-headed garlic shared none of the evaluated polymorphisms. The accession of A. polyanthum from Ile d'Yeu (France) was identical to the Spanish accession of greatheaded garlic for all evaluated polymorphisms in the chloroplast and nuclear $45 \mathrm{~s}$ rDNAs (Figs. 4 and 5).

Pollination studies. An umbel of chinese bulbous leek pollinated with leek produced ten seeds, four of which germinated. RAPD analysis of individual parent plants compared to the progeny confirmed their hybrid origin (Fig. 6). 列 previously published descriptions of A. ampeloprasum (Koul and Gohil, 1970; Jones, 1990). Supernumerary chromosomes, which occur in some Allium species, often termed B-chromosomes, are small and variable in number. Jones (1990) reported zero to three additional B-chromosomes in leek. B-chromosomes were found in up to $30 \%$ of commercial leek samples and their presence may slightly enhance seed germination. Additional B-

Fig. 5. Autoradiogram showing EcoRI polymorphisms in the nuclear 45 s ribosomal DNA among the alliums listed across the top. Sizes in kilobases of smaller fragments listed on right. chromosomes were reported for triploid A. ampeloprasum var. truncatum (Kollmann, 1971); Guern etal.(1991) found one B-chromosome in A. polyanthum and Bothmer(1982) found one to two B chromosomes in A. commutatum.

Our results unambiguously demonstrate that our accession of chinese bulbous leek is not garlic, but a previously undescribed variant within the $A$. ampeloprasum group. The cpDNA hybridizations revealed shared autapomorphic characters with $A$. ampeloprasum. Because the accession of chinese bulbous leek was used locally as garlic, it is possible that long-term selection shifted the morphological characteristics in the direction of garlic-like cloves. However the taste was not the same as that of garlic, which was more pungent and had lower crispness. We also demonstrate that this accession of bulbous leek resembles closely the bulbous leek forms indigenous to Europe.

In contrast to several previously published classifications (Hanelt, 1990; Fritsch and Friesen, 2002; Mathew, 1996; Messiaen et al., 1993; Van der Meer, 1997), it seems likely that studied accessions of great-headed garlic are not closely related to the tetraploid forms of A. ampeloprasum group. On average the $1 \mathrm{C}$ value of genome size of great-headed garlic was $17 \%$ bigger than those of the studied leek and bulbous leek accessions. Chloroplast DNA polymorphisms demonstrated that greatheaded garlic possessed same progenitor states as $A$. polyanthum and $A$. commutatum and did not share the derived states with the $A$. ampeloprasum group (leek and its tetraploid bulbous forms). RFLPs in the nuclear $45 \mathrm{~s}$ ribosomal DNA showed similar genetic relationships. This very preliminary result showed that great-headed garlic may be more closely related to tested wild Allium species than to A. ampeloprasum and A. sativum. However a comparison to a wider range of wild Allium relatives and to A. ampeloprasum accessions of various ploidies should be included in further studies to reveal its origin.

\section{Literature Cited}

Bothmer, R. 1982. Karyotype variation in Allium commutatum (Liliaceae s. Iato). Plant Syst. Evol. 140:179-189.

Brewster, J.L. 1994. Onions and other vegetable alliums. CAB Intl., Wallingford, U.K.

Campion, B., B. Bohanec, and B. Javornik. 1995.

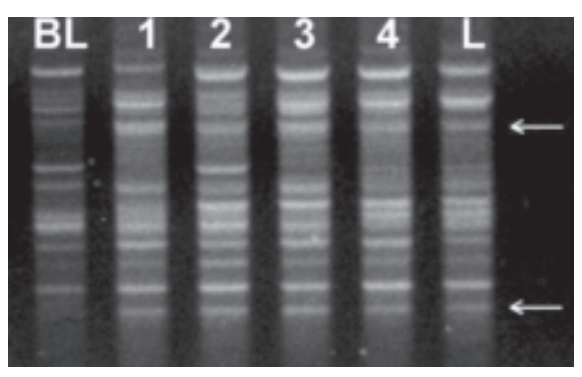

Fig. 6. Amplification of pattern RAPD primer OPA-20. BL = chinese bulbous leek, female parent, 1 to 4 hybrid progeny, L = 'Ardea' leek, male parent. Arrows indicate bands present in pollen donor and in progenies but not in the female parent. 
Gynogenic lines of onion (Allium cepa L.): evidence of their homozygosity. Theor. Appl. Genet. 91:598-602.

Dolezel, J., P. Binarová, and S. Lucretti. 1989. Analysis of nuclear DNA content in plant cells by flow cytometry. Biol. Plant. 31:113-120.

Dolezel, J. Greilhuber, S. Lucretti, A. Meister, M.A. Lysak, L. Nardi, and R. Obermayer. 1998. Plant genome size estimation by flow cytometry: Interlaboratory comparison. Ann. Bot. 82:17-26.

Fritsch, R.M. and N. Friesen. 2002. Evolution, domestication and taxonomy, p. 5-30. In: H.D. Rabinowitch, and L. Currah (eds.). Allium crop science: Recent advances. CABI Publ., Wallingford, U.K.

Guern, M., J. LeCorff, and J. Boscher. 1991. Comparative karyology of the Allium ampeloprasum complex in France. Bul. Soc. Bot. Fr.-Lett. Bot. 138:303-313.

Hanelt, P. 1990. Taxonomy, evolution, and history, p. 1-26. In: H.D. Rabinowitch, and J.L. Brewster, (eds.). Onions and allied crops. vol. 1. CRC Press, Boca Raton, Fla.
Havey, M.J. 1991. Phylogenetic relationships between cultivated Allium species from restriction enzyme analysis of the chloroplast genome. Theor. Appl. Genet. 81:752-757.

Havey, M.J. 1992. Restriction enzyme analysis of the nuclear $45 \mathrm{~s}$ ribosomal DNA of six cultivated alliums. Plant Syst. Evol. 181:45-55.

Havey, M.J and D.L. Leite. 1999. Toward the identification of cytoplasmic male sterility in leek: evaluation of organellar DNA diversity among cultivated accessions of Allium ampeloprasum. J. Amer. Soc. Hort. Sci. 124:163-165.

Jones, R.N. 1990. Cytogenetics, p. 199-214. In: H.D. Rabinowitch, and J.L. Brewster (eds.). Onions and allied crops. vol. 1. CRC Press, Boca Raton, Fla.

Kollman, F. 1971. Allium ampeloprasum-A polyploid complex I. Ploidy levels. Israel J. Bot. 20:13-20.

Koul, A.K. and R.N. Gohil. 1970. Cytology of the tetraploid Allium ampeloprasum with chiasma localization. Chromosoma 29:12-19.

Mathew, B. 1996. A review of Allium section Al- lium. Royal Botanic Gardens, Kew, Richmond, Surrey, U.K.

Messiaen, C.M., J. Cohat, M. Pichon, J.P. Leroux, and A. Beyries. 1993. Vegetatively propagated edible alliums. INRA, Paris.

Puizina, J., B. Javornik, B. Bohanec, D. Schweizer, J. Maluszynska, and D. Papeš. 1999. Random amplified polymorphic DNA analysis, genome size, and genomic in situ hybridization of triploid viviparous onions. Genome 42:1208-1216.

Saghai-Maroof, M.A., K.M. Soliman, R.A. Jorgensen, and R.W. Allard. 1984. Ribosomal DNA spacer length polymorphism in barley: Mendelian inheritance, chromosomal location and population dynamics. Proc. Natl. Acad. Sci. USA Biol. Sci. 81:8014-8018.

Van der Meer, Q.P. 1997. Old and new crops within edible Allium, p. 17-31. In: J.L. Burna and C. Galmarini (eds.). Proc. 1st Intl. Symp. Edible Alliaceae. Acta Hort. 433.

Walters, T.W. 1992. Rapid nuclear DNA content estimation for Allium spp. using flow cytometry. Allium Improv. Nwsl. 2:4-6. 